\title{
Pump Loss Estimation in Experimental Gas Hydrate Creation Site
}

\author{
Peter Durcansky ${ }^{1,}$, , Milan Malcho ${ }^{1}$, Richard Lenhard ${ }^{l}$, and Juraj Drga ${ }^{l}$ \\ ${ }^{1}$ University of Žilina, Faculty of Mechanical Engineering, Department of Power Engineering, \\ Univerzitna 1, 01026 Žilina, Slovakia
}

\begin{abstract}
Gas hydrates are considered a global phenomenon that, as an unconventional fossil fuel, can be an alternative energy source for the future. Hydrates form spontaneously in permafrosts and marine sediments, where the conditions for their formation are naturally suitable - low temperature and high pressure. The energy of hydrates could replace or supplement the most commonly used fossil fuels today. Hydrates are also an advantageous solution to the problem of natural gas storage. The main part of the experimental equipment operated is a pump, which generates the pressure energy needed to form hydrates. The article deals with the assessment of the effectiveness of the current state and the estimation of losses in the pipelines of the facility.
\end{abstract}

\section{Gas hydrate creation site}

Our department developed new method for gas hydrate creation. The schema is shown in next picture. The device was designed according to known parameters of methane hydrate formation process. The experimental device consists of 2 main parts - methane part and water part. The methane part consists of a gas source, compressor and injection nozzle. The water part consists of pressure reservoir, where the water is stored, pump and cooler. These lines are connected in injection nozzle, where the hydrate in reactor and in hydrate separator is created. Pressure of water and gas can be adjusted, and also the nozzle opening pressure can be set independently. This allows to study the behavior of hydrate forming process and impact of pressure at forming conditions.

\footnotetext{
*Corresponding author: peter.durcansky@,fstroj.uniza.sk
} 


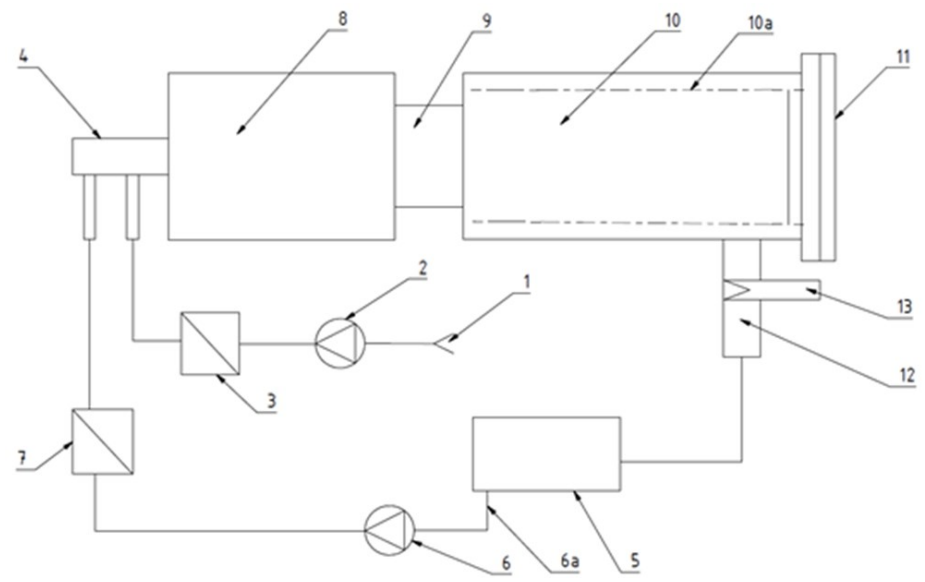

1- Gas source

2-Compressor

3- Gas cooler

4- Injection nozzle

5- Pressure water reservoir

6- pump

6a pump suction pipe

7- water cooler

8 reactor

9- Mixer collector

10- Hydrate separator

10a- Filter element

11- Removable lid

12- Overflow pipe

13- Pressure reducing valve

Fig. 1. Proposed gas hydrate creation site.

The gas is compressed from the gas source, additionally cooled in the cooler and fed to the injection nozzle. Hydrate particles are formed as a result of the high pressure. These are then entrained by the stream of the resulting mixture into the mixture collector and subsequently stream into the hydrate separator with the filter element on which they are trapped under pressure to form clusters of molecules and gradually fill the space of the separator. But there is still the need to cool down the mixture, so a variation of previous experimental equipment was developed $[1,2]$. The system is shown in Figure 1.

The hydrate particles that pass through the filter cartridge of the hydrate separator in the previous cycle are re-saturated with gas in the reactor, thereby increasing their dimensions and after passing through the mixture collector are retained on the filter cartridge. After filling the hydrate separator, the produced hydrate can be removed through a removable lid.

\section{Pressure loss in the system}

The energy consumption of the experimental equipment consists of the consumption of the compressor, the pump and the energy consumption of the refrigeration equipment. It is determined on the basis of their power inputs in $\mathrm{kW}$, which are multiplied by the price of electricity per $1 \mathrm{kWh}$. An important energy device of the experimental device is the circulating pump. The pump must transmit a sufficiently large pressure energy to the fluid to ensure a smooth flow of fluid up to the nozzle and to overcome pressure losses - local and friction [2]. Local losses occur when the flow direction changes abruptly, when the flow cross section changes or when the liquid passes through the valve. Friction losses are caused by the liquid flow around the technologically rough surfaces of the piping system [3].

Figure 2 shows the route that the water must travel from the pump to the nozzle.

From the pump to the nozzle, water flows through 3 technologically different surfaces of the piping system, which have different lengths and flow cross-sections.

The first section consists of a SEL PN - WP 400 bar hose, $3 \mathrm{~m}$ long, on which a shut - off valve is fitted. The value $\xi=0.2$ is used in the calculation as the loss factor of the local loss for the shut-off valve. This value of the loss factor applies when the valve is fully open. The first section is connected to the second by a coupling [4]. 


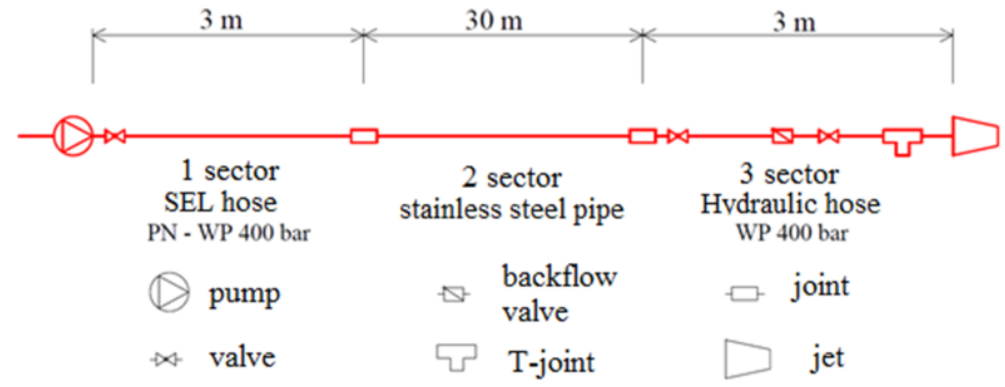

Fig. 2. Flow diagram of fluid from pump to nozzle.

At this point, the flow cross-section narrows. The loss coefficient of the sudden narrowing of the cross-section at the point of water flow through the coupling is $\xi=0.73$. The second section consists of a stainless steel seamless pipe, $30 \mathrm{~m}$ long. This tube is part of the cooling vessel. It is connected to the third section by a coupling, where the flow cross-section widens. The loss coefficient of the sudden current narrowing is in this case $\xi=0.05[5]$.

The third section consists of a Hansa-flex hose, WP 400 bar, $3 \mathrm{~m}$ long. In this section, there are 4 fittings through which water flows before entering the nozzle, namely 2 shut-off valves, a non-return valve with a value of the loss coefficient of local resistance $\xi=2$ and a T-piece with a loss coefficient of local resistance $\xi=0.9[6,7]$. Loss coefficients are chosen on the basis of the literature $[8,9]$.

The local pressure losses $\mathrm{Y}_{\mathrm{SM}}$ were calculated for each section separately according to the relation:

$$
Y_{S M}=\sum_{i=1}^{n} \xi_{i} \frac{v_{i}{ }^{2}}{2}
$$

The resulting local pressure losses represent the sum of the losses of the individual sections. Input data and calculation results are shown in Table 1.

Table 1. Local pressure loss.

\begin{tabular}{|c|c|c|c|}
\hline & 1st section & 2nd section & 3rd section \\
\hline & $\begin{array}{c}\text { hose SEL PN - WP } \\
400 \text { bar }\end{array}$ & $\begin{array}{l}\text { Stainless steel } \\
\text { pipe }\end{array}$ & $\begin{array}{l}\text { hose Hansa-flex, } \\
\text { WP } 400 \text { bar }\end{array}$ \\
\hline Pipe diameter $\mathrm{d}[\mathrm{m}]$ & 0.00953 & 0.007 & 0.00635 \\
\hline Flow velocity $\mathrm{v}\left[\mathrm{m}_{\mathrm{s}} \mathrm{s}^{-1}\right]$ & 1.19 & 2.21 & 2.68 \\
\hline \multicolumn{4}{|l|}{ Loss factor $\xi[-]$} \\
\hline Closing valve factor & 0.20 & - & 0.20 \\
\hline joint & 0.73 & 0.05 & - \\
\hline Backflow valve & - & - & 2.00 \\
\hline T-joint & - & - & 0.90 \\
\hline $\begin{array}{c}\text { Local losses on individual } \\
\text { sections } \\
{\left[\mathrm{J}_{\mathrm{kg}} \mathrm{kg}^{-1}\right]}\end{array}$ & 0.66 & 0.11 & 11.89 \\
\hline Local pressure losses $Y_{S M}$ & \multicolumn{3}{|c|}{$12.66 \mathrm{~J} . \mathrm{kg}^{-1}$} \\
\hline
\end{tabular}


The friction losses $Y_{S T}$ caused by the friction of the flowing water on the inside of the piping system along its length are calculated according to the relation:

$$
Y_{S T}=\sum_{j=1}^{n}\left(\lambda_{j} \cdot \frac{l_{j} \cdot v_{j}^{2}}{d_{j} \cdot 2} \cdot \rho\right)
$$

The input data and the resulting values of the relation are given in Table 2 . The coefficient of friction loss for a given type of inner surface of the pipe is chosen according to the material of the hose or pipe based on the manufacturers literature.

Table 2. Total friction losses.

\begin{tabular}{|c|c|c|c|}
\hline & 1st section & 2nd section & 3rd section \\
\hline & $\begin{array}{c}\text { hose SEL PN - WP } \\
400 \text { bar }\end{array}$ & $\begin{array}{l}\text { Stainless } \\
\text { steel pipe }\end{array}$ & $\begin{array}{c}\text { hose Hansa-flex, WP } \\
400 \text { bar }\end{array}$ \\
\hline Lenght $l[\mathrm{~m}]$ & 3 & 30 & 3 \\
\hline Pipe diameter $d[\mathrm{~m}]$ & 0.00953 & 0.007 & 0.00635 \\
\hline Flow velocity $v\left[\mathrm{~m} \mathrm{~s}^{-1}\right]$ & 1.19 & 2.21 & 2.68 \\
\hline Density $\rho\left[\mathrm{kg} \cdot \mathrm{m}^{3}\right]$ & 997 & 997 & 997 \\
\hline Loss factor $\lambda[-]$ & 0.010 & 0.002 & 0.010 \\
\hline $\begin{array}{c}\text { Friction losses in individual } \\
\text { sections }\left[\mathrm{J}_{\mathrm{kg}} \mathrm{kg}^{-1}\right]\end{array}$ & 2228.33 & 20844.16 & 33931.72 \\
\hline Total friction losses $Y_{S T}$ & \multicolumn{3}{|c|}{$40038 \mathrm{~J} \mathrm{~kg}^{-1}$} \\
\hline
\end{tabular}

The total mechanical energy $Y_{P}$ supplied by the pump to the pumped liquid can be calculated on the basis of the specific mechanical energy of the pump and the specific loss energy of the pump from previous tables.

\section{Conclusions}

In the current state, the water is sucked in by a high-pressure pump, through which it flows in the entire closed system under a pressure of $25 \mathrm{MPa}$. At the end of each cycle, it passes through a pressure reducing valve, where the value of the fluid pressure decreases to its original value of $0.5 \mathrm{MPa}$. This cycle is repeated throughout the formation of hydrates, which represents a consumption of $4.7 \mathrm{kWh}$. The pump of the experimental device sucks in a low pressure liquid of approx. $0.5 \mathrm{MPa}$ and transmits the mechanical energy of an external source in the form of pressure energy through the active part - the plunger, whereby the outlet pressure of the liquid acquires the value of $25 \mathrm{MPa}$, which represents the power of the pump $4.66 \mathrm{~kW}$. In the proposed measure, another plunger pump will be included in the closed system [12]. The first cycle will ensure the transport of the liquid in the system by the original pump, but at the end of it the pressure of the liquid will not be reduced through the reduction valve, but the liquid will be sucked in by the second plunger pump, thus reducing consumption [13]. Despite the proposed measure, the mechanical energy of the pump is relatively high due to the large specific energy loss. Reducing pressure and friction losses could therefore provide additional scope for improving the energy efficiency of the experimental equipment. 
Acknowledgements: Work on article has been financially supported by the project VEGA-1/0738 / 18 „Optimization of energy inputs for the rapid generation of natural gas and bio methane hydrates for the accumulation of high potential primary energy “, the project KEGA-063ŽU-4/2018 „Depositing hydrocarbon gases into hydrate structures as an alternative energy storage method "and "Influence of combustion conditions on production of solid pollutants in small heat sources", VEGA 1/0479/19.

The project is published within "Research and development of waste-free technology for decomposition and selection of undesirable components from process gas generated by gasification equipment" APVV-17-0311.

\section{References}

1. A. Demirbas, Energy Conversion and Management, 51, 7 (2010)

2. V. Foltin, J. Rajzinger, M. Juriga, Š. Gužela, Nové zdroje zemného plynu: bridlicový plyn a zemný plyn viazaný v hydrátoch, SSTP, Bratislava (2013)

3. E. S. Harrison, Natural Gas Hydrates," in Submitted as course for Physics 240, Stanford University, Fall (2010)

4. M. Maslin, Gas hydrates: past and future geohazard, 368, 1919 (2010)

5. K. A. Kvenvolden, G. D. Ginsburg, V. A. Soloviev, Worldwide distribution of subaquatic gas hydrates, Geo-Marine letters, 13, 1, 32-40 (1993)

6. T. Daimaru, M. Fujii, A. Yamasaki, Y. Yanagisawa, Energy saving potential for natural gas hydrate transportation. Japan (2004)

7. M. C. G. Chacin, R. G. Hughes, F. Civan, C. E. Taylor, Phenomenological modeling of hydrate formation and dissociation. In Advances in the Study of Gas Hydrates; Taylor (2004)

8. A. M. Pavlenko, H. V. Koshlak, B. O. Usenko, Basic principles of gas hydrate technologies. Thermal technology, metal jorunal publishing (2014)

9. D. T. Brown, E. Ch. Taylor, P. M. Bernardo, Rapid Gas Hydrate Formation Processes: Will They Work? Energies 3 (2010)

10. S. Circone, CO2 Hydrate: Synthesis, Composition, Structure, Dissociation Behavior, and a comparison to Structure I CH4 Hydrate. J. of Phys. Chem. B (2003)

11. M. Patsch, A. Caja, Analysis of long-time operation of micro-cogeneration unit with fuel cell, Conference: 9th International Conference On Experimental Fluid Mechanics, EPJ Web Of Conferences, 92, Article Number: 02061 (2014)

12. J. Jandacka, M. Holubcik, Š. Papucik, R. Nosek, Combustion of pellets from wheat straw, Acta Montanistica Slovaca, 4, 17 (2012)

13. L. J. Orman, N. Radek, A. Kapjor, Surface Treatment Technologies for Boiling Heat Transfer augmentation, Terotechnology, 2017, Materials Research Proceedings, 216219, 5 (2018) 